\title{
Integrating Business CSR with Local Government Development Program: Business Perception
}

\author{
Abdul Nadjib \\ Universitas Sriwijaya \\ E-mail: anadjib.salatti@gmail.com \\ Rabin Ibnu Zainal \\ Universitas Bina Darma \\ E-mail: rabin.zainal@ binadarma.ac.id
}

Received: March 4, 2020 Accepted: March 23, 2020 Online published: April 29, 2020

doi:10.5296/jpag.v10i2.16611～URL: https://doi.org/10.5296/jpag.v10i2.16611

\begin{abstract}
The mandate of Corporate Social Responsibility (CSR) in Indonesia through various laws and regulations, provide an alternative source of funding for local government for the development and the provision of basic services in their area. However, the process of integrating business CSR with local development program must consider the perception of all relevant stakeholders, namely local government officials and staff or managers managing CSR programs in the company. Business CSR are often placed as an instrument for companies to achieve its interest, such as to obtain a social license, reputation and security of business. This study is aimed at understanding business perceptions in integrating business CSR with local development program. The study took place in Muara Enim Regency, South Sumatra province, which is known as a regent where many mining and plantation companies operating in the region. The method used is a descriptive qualitative research method by conducting unstructured interviews with managers and staff of 10 business companies in this region. The study found that there were differences in perceptions of managers and staff towards the integration of CSR with local development programs. The differences of perception is occurred as the local government is still not adopted the business interests. This can be used as a guideline for all parties as a first step to integrate CSR programs with regional development planning.
\end{abstract}

Keywords: CSR, local government, development programs, Indonesia 


\section{Introduction}

Most studies and practices of Corporate Social Responsibility (CSR) in other countries put the CSR program as a form of voluntary from business companies (Schwartz and Carroll, 2003). CSR is an approach in which companies integrate their social responsibilities in their business operations and in their interactions with stakeholders based on the principle of volunteerism and partnership (Nuryana, 2005). The principle of volunteerism and partnership which is emphasized in the above definition, was changed since 2007 in Indonesia, which emphasizes CSR as a mandate for business companies related to the natural resource sector and operating in Indonesia, as stated in Article 74 paragraph 1 of the Law Law 40 of 2007 concerning Limited Liability Companies (Marnelly, 2012). As an implementing regulation of this law, on 4 April 2012 the government established Government Regulation No. 47 of 2012 concerning Limited Corporate Social and Environmental Responsibility (Richardo et al., 2013).

The reason for the issuance of this legislation is because Indonesia's development still requires a lot of infrastructure development, services, and better education and health social security for its residents. This situation has caused the government to start searching for the business to take a role in social provision, where CSR plays a major role in motivating companies operating in Indonesia to involve themselves in local development assisting the government in providing public goods and services (Zainal, 2019). CSR, in this context, is placed as an alternative source of funding for regional development, in addition to the Regional Budget (APBD) and the National Budget (APBN).

Muara Enim Regency is known as one of the regions in Indonesia that has rich natural resources such as mining products (coal, oil and gas) and plantation (rubber and palm oil). Support from the company in these sectors is needed to help the local government development program. There are limitations in development funding for the Muara Enim Regency Government compared to the programmed development funding needs. On the other hand, business companies operating in Muara Enim Regency also carry out community development activities through the Corporate Social Responsibility Program. From the side of the company itself, the application of CSR has begun to be widely carried out and is one of the ways companies in an effort to improve their image and reputation.

With this aim, CSR programs should be directed to be integrated with local development planning. Muara Enim Regency made this effort by forming the Corporate Social Responsibility Forum (CSR Forum), which consists of all companies located and operating in the Muara Enim Regency area (Partini, 2013). In addition, the regional government itself, through the Regional Development Planning Agency (Bappeda), makes a non-APBD Regional Government Work Plan (RKPD), which contains local government work programs as the results of the Muara Enim District Development Planning Meeting (Musrenbang) that can be funded by alternative funding sources outside the APBD, including by business companies through their CSR funds.

However, the process of integrating CSR with development programs from local governments is not easy. CSR programs are built based on business interests, especially 
related to the company's motives for continuing to seek profit (Carroll and Shabana, 2010; Friedman, 2007). So that every CSR program of a business company is always associated with a motive for the company's reputation, or obtaining a social license to operate from the community around the company (Famiyeh et al., 2019). On the other hand, the regional government development program is based on the interests of the bupati (local regency head) as a manifestation of the vision and mission that has been conveyed during the campaign period of the elected regional head (Esa, 2016). That is, the integration of CSR programs and regional development programs need to consider the interests of each party, namely the business company and the regional government.

This research will focus on identifying business perceptions of initiatives to integrate CSR with regional development planning programs. Hopefully, this research will contribute to policy makers to be able to make strategies on how to integrate CSR programs and development planning programs while still taking into account the interests of business in CSR.

Based on the preliminary description in the background section above, this research aims to take the research main problems regarding, "What is the business perception of the integration of CSR programs and regional development planning programs?". The specific questions for this research are: (1) What is the business perception of the local government development program? (2) What form of integration is expected by the business company?

Based on the research questions above, this study aims primarily to identify business perceptions of the integration of CSR programs and regional development programs. The specific objectives that can be achieved from this research are: (1) Knowing business perceptions on the development programs from local governments; (2) Analyzing possible forms of cooperation to be carried out for the integration of CSR programs and regional development.

\section{Literature Review}

\subsection{Mandated CSR in Indonesia}

The Indonesian government has issued a different policy from most other countries by introducing mandating business companies to carry out CSR through the laws (Rosser and Edwin, 2010). Furthermore, Zainal (2019) has identified the legislation that bind business companies related to natural resources to be required to implement CSR. The foundation of the regulation on Indonesian CSR starts with Article 33 of the 1945 Constitution (1945 Constitution - Indonesian Constitution) with its statement that natural resources must provide welfare for the people of Indonesia, including local communities. From this position, the CSR law was formed. There are four specific CSR laws that have direct relevance to their company's operations, namely: (i) Law No. 40/2007 concerning Limited Liability Companies, requires companies related to natural resources to carry out CSR; (ii) Law No. 25/2007 on Investments, which details CSR compliance for all investors; (iii) Law Number 22 Year 2001 regarding Oil and Gas, states that Community Development (CD) is an obligation of Oil and Gas companies for local communities; and (iv) Law No. 19/2003 concerning State-Owned 
Enterprises, which states the obligation to deliver the Environmental Development and Partnership Program (PPEB) (or in Indonesian, the PKBL Partnership and Community Development Program program) for State-Owned Enterprises (SOC). Apart from these laws, two other relevant laws, namely: (v) Law No. 11/2009 concerning Social Welfare; and (vi) Law No. 13/2011 concerning Poverty.

This law allows government intervention in corporate CSR decisions, which may differ from most business practices in other countries found in the CSR literature, which assumes volunteerism and self-determining policies in corporate CSR decisions (Carroll, 1991). In addition, Donaldson and Dunfee (1999) argue that in the practice of CSR with volunteerism, the community and local government only have implicit claims to CSR from business companies. This is because unlike consumers, suppliers or shareholders, who have explicit claims in the sale and purchase contract, or shareholder rules, the local community does not have an explicit contractual agreement with the company. However, the issuance of CSR laws in Indonesia changed the status of claims, which turned the CSR claims into explicit claims for the government and local communities, and increase local stakeholder demands for corporate CSR contributions.

\subsection{Local Development Planning Process}

The development planning approach from centralized to decentralized, by prioritizing the authority of regional autonomy, began since the reform era in 1998. The approach taken in development planning from top-down to bottom-up, has given greater authority to the regions to manage their own area. This authority is guaranteed by the issuance of Law Number 22 of 1999 concerning Regional Government, which is followed by Law Number 25 of 1999 concerning Central and Regional Financial Balances. Subsequently the two Laws were refined into Law Number 32 of 2004 concerning Regional Government and followed by Law Number 33 of 2004 concerning Central and Regional Financial Balances (Hasan, 2018). Furthermore, this regulation was revised again through Law number 23 of 2014 concerning local government, where some district authorities were handed over to the provincial government, such as those in the mining and forestry sectors.

Since the issuance of Law No. 25/2004 concerning the National Development Planning System (SPPN) and Law No. 32/2004 concerning Regional Government, the substance and essence of the development planning system at the national and regional levels becomes increasingly necessary to be established, in order to better guarantee the implementation of development in the centre and regions that are more effective and efficient. Law No. 25 of 2004 concerning the National Development Planning System mandates that each region must prepare regional development plans in a systematic, directed, integrated and responsive manner to changes (Article 2 paragraph 2), with long-term planning levels (25 years), medium term (5 years) or short term or annual (1 year). Each region (province / district / city) must determine the Regional Long-Term Development Plan (RPJPD), the Regional Medium-Term Development Plan (RPJMD) and the Regional Government Work Plan (RKPD).

The same development planning process was also applied in Muara Enim district. The 
process of extracting aspirations from the community starts with the Village Development Planning Consultation (Musrenbang). Then the results of the Musrenbangdes are taken to the district level. And finally passed on to the District Musrenbang level. Proposed programs and activities are used as a reference for making Local Government Work Plans (RKPD), and become directions for the process of making the Regional Budget (APBD). For program plans and activities that are not included in the District APBD, the local government prepares a non-APBD RKPD to provide opportunities for business companies operating in Muara Enim thorugh their CSR, to contribute to the development programs that have been prepared (Nadjib, 2019).

\subsection{CSR Program Planning Process}

Discussing how business companies plan CSR programs can not be inseparable from their motivation in CSR. Various definitions of CSR indicate that business motivation for CSR varies. Based on narrow definitions, rational explanations for businesses that impose CSR depend on economic motives; while in a broad definition, the motive can be in the form of ethics or law fulfillment. In connection with this definition, the Schwartz and Carroll (2003) CSR model proposes three domains of influence on the firm's decision to implement CSR. These are: (1) economics, (2) law, (3) ethical (see Figure 1). This model was developed from the CSR pyramid written by Carroll (1991); However, Schwartz and Carroll (2003) removed the philanthropic domain from their model, because in reality philanthropic business activities such as giving to charity could be considered driven by ethical or economic motives.

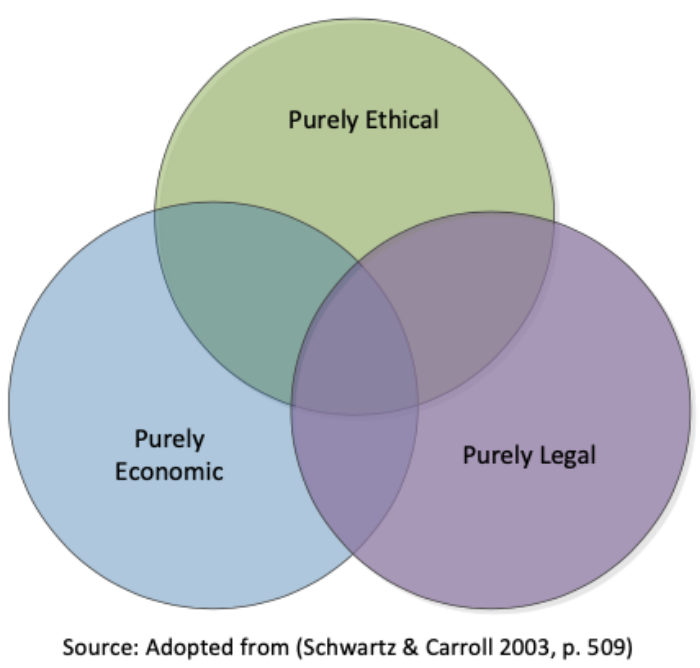

Figure 1. Three Domains of CSR

Figure 1 shows that the three domains of economic, ethical and legal responsibility overlap and interact to drive companies to do CSR. Schwartz and Carroll (2003) argue that CSR activities are rarely motivated from within one domain. The ideal overlap is at the centre of the model, where economic, legal and ethical responsibilities are simultaneously met. The three grey domains and areas in the model represent the real situation in the company, which must be explored and analysed as a basis for decision makers in business companies in 
creating CSR programs. As Graham and Woods (2006) point out, voluntary initiatives stemming from economic and ethical motives can include mandatory aspects as mandates from regulations made by government.

Based on the above model, business companies have their own motives and interests in implementing CSR, namely in terms of economic motivation such as to obtain social and security licenses from stakeholders around the company, or as an ethical goal of corporate management. For this reason, many companies develop their own CSR program models and plans that are appropriate to their business and ethical goals (Zainal, 2006).

Rachman et.al. (2011) in his book titled complete guidelines for CSR planning, also states that companies need to develop community participation around the company's operations, in order to obtain programs that are appropriate and needed by local communities. Various methods such as deliberation and discussion with local stakeholders were developed by business company managers related to CSR to capture the program's aspirations from the local community and adapt it to the interests of the company.

\subsection{CSR Forum}

The issuance of CSR regulations on business mandate in Indonesia is based on the perspective of seeing CSR as an alternative source of funding for development in Indonesia. Limited funding sources for development in Muara Enim, has encouraged the Muara Enim District Government to establish a CSR forum which is a forum for all business companies operating in the Regency, to contribute to development in Muara Enim. On the official website of the Muara Enim CSR-PKBL Forum, the background to the establishment of the CSR forum consists of the following issues (Bappeda Muara Enim, 2019):

- Community dissatisfaction

- Overlapping programs between companies and with the government

- Monitoring and evaluation of CSR implementation is still one-sided by the corporation

- Community proposals that are not followed up without explanation

- There is a throwing of responsibilities between corporations, the government and the community

- Community and environmental development is also the responsibility of the company.

The CSR forum is used by the government to offer development programs, which are derived from the aspirational selection process through the village to district level Musrenbang, and cannot be budgeted in the APBD. All non-budgeted programs are included in non-APBD RKPD documents and can be selected by business companies incorporated in the CSR Forum.

The results of the CSR forum showed the contribution of business firms to increase in the construction of Muara Enim. Based on media publications, in 2018, the contribution of CSR and PKBL to the development of Muara Enim was recorded at Rp. 88.71 billion from 14 companies. This number has increased compared to 2017, where the company's CSR in Muara Enim was Rp. 83.82 billion, contributed by 23 companies. Even though the number of 
companies has decreased, the number of CSR financing contributions has increased from 2017 to 2018 (Zuhri, 2018).

The process of integrating CSR programs and development programs also needs to pay attention to the interests of each party, in this case business companies and local governments. For local governments, forming a CSR forum can help the government to obtain alternative funding sources in the midst of budget constraints for development programs. However, an important question for this study is whether the interests of business companies in carrying out CSR are accommodated in the process of integrating Development and CSR programs. Knowing business perceptions is very important so that social investment carried out by business companies also has a return for business (Hinson and Ndhlovu, 2011), both in the form of security guarantees for businesses through social license to operate (Famiyeh et al., 2019), increasing the company's reputation in the market (Rahmayanti, 2014), or other goals that are inseparable from the company's business interests.

\section{Research Method}

This research focuses on the perception of business companies towards integrating government development planning and CSR programs. A qualitative approach was taken for this research, to understand the perspectives and perceptions of business companies. Perception is an individual response to social phenomena, where this perception arises due to the results of interaction and interpretation (Creswell and Poth, 2016), especially related to the integration process of CSR and government development programs. Information from interviews with managers from selected companies about the impact of the integration of CSR and development programs is complex. Thus, standardized data collection methods such as surveys will be too rigid for the type of information sought for this study.

The definition of qualitative research can be found in many literatures, among others, Ali and Yusof (2011) define qualitative research as, "any investigation which does not use statistical procedures is called" qualitative "nowadays, as if this was a quality label in itself ". The definition, emphasizes the absence of the use of statistical tools in qualitative research. Meanwhile, the qualitative method emphasizes the observation of phenomena and examines the substance of the meaning of the phenomena. The analysis and sharpness of qualitative research is greatly affected by the strength of the words and sentences used. Therefore, Basri (2014) concludes that the focus of qualitative research is on the process and the meaning of the results.

The study took 10 companies in Muara Enim district and joined the CSR forum. Data collection is done by in-depth interview approach to informants who have the capability to answer questions that are asked by taking into account position positions primarily, related to the decision making of CSR programs in selected companies.

The informants' descriptions of the 10 selected companies are as follows: 
Table 1. Informant Criteria

\begin{tabular}{|l|cc|}
\hline \multicolumn{1}{|c|}{ Criteria } & Description \\
\hline Informant Position & $\bullet \begin{array}{c}\text { Working in the department / unit / section that } \\
\text { manages the company's CSR. } \\
\text { In the position of middle manager } \text { or top manager }\end{array}$ \\
\hline Specific Criteria & $\bullet \begin{array}{c}\text { A decision maker in the company related to the } \\
\text { planning of Company's CSR program }\end{array}$ \\
\hline
\end{tabular}

Codes will be used to ensure the confidentiality of informants and companies participating in this research, by changing the company names with numbers. Interviews related to business enterprise perceptions of development planning in local governments, expected forms of integration, and forms of cooperation were distributed to 10 informants representing 10 companies.

The data analysis method used in this research is the 'descriptive case' method to manage case studies according to the complexity of the case. This method allows researchers to describe and relate the context of each case. In line with this strategy, an explanation building technique is used to explain a phenomenon, by answering the 'how' and 'why' questions of the findings obtained in the interview results (Patton, 2014).

\section{Findings}

\subsection{Business Perception on Local Government and Development Planning Program}

Before determining the business decision on the integration of CSR programs with local government development programs, we need to know about businesses perceptions toward local government and the planning of development programs. The 10 informants from the company gave different perceptions on these matters. Perceptions of government programs and local governments themselves can be seen in the table below:

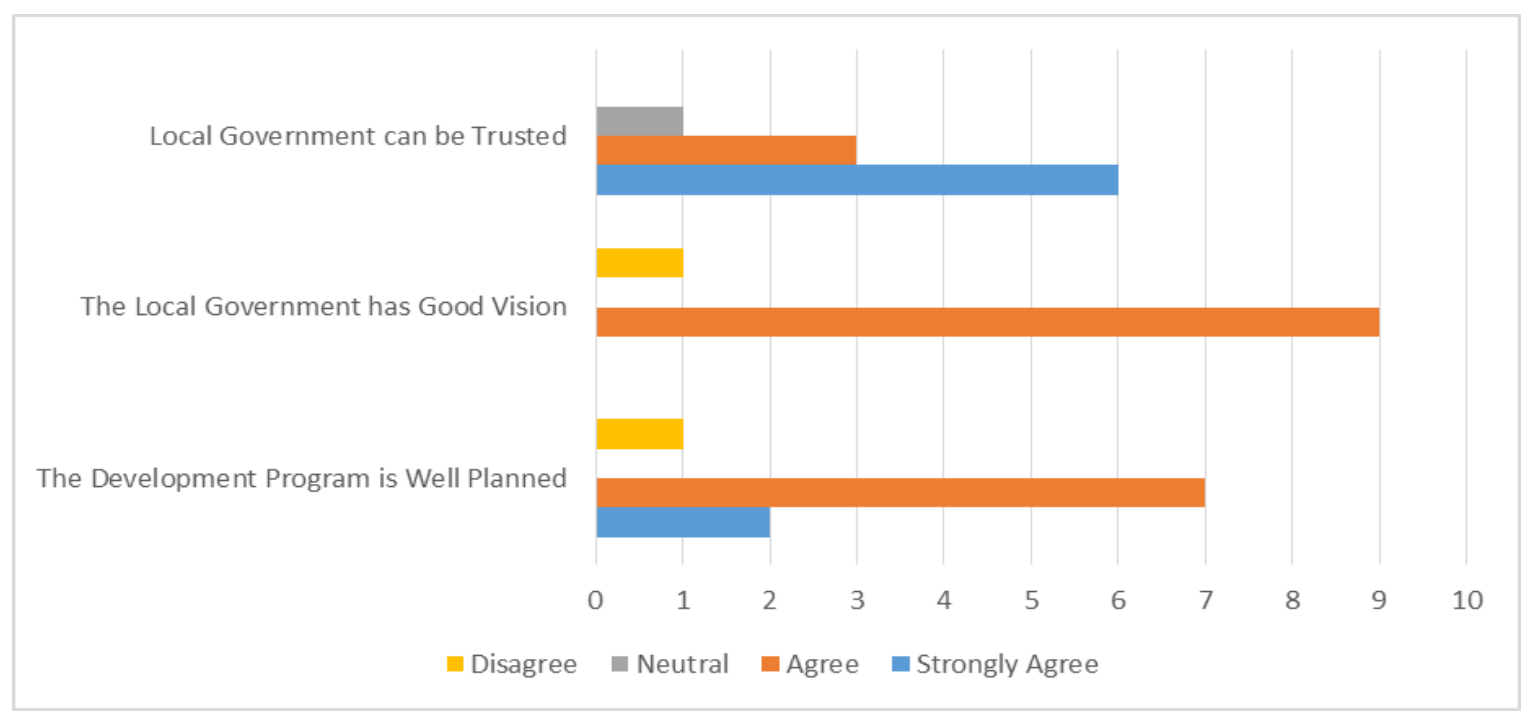

Figure 2. Perception of Businesses on Local Government and Development Program

Source: Interview, 2018 
The figure 2 shows the perception of 10 managers and staff in responding about the trust to local government, the vision of local government and the local development programs. In terms of the level of trust in the local government, apparently 6 informants are strongly agreed that the local government can be trusted, while only 3 informants who answered agree. Whereas the level of trust towards Local Government itself is still dominated by good perception, only 1 informant answered disagree that local government can be trusted. In responding about the vision of local government, 9 informants from businesses agree that government has good vision, while only 1 informant disagree that government gas good vision. Finally, related to perceptions of development planning, most respondents strongly agree ( 2 informants) and agree ( 7 informants), considered the development program is well planned, and there is 1 informant who actually considers the regional government development planning is disagreed that the development program is well planned.

This indicates that the business considers that the regional development planning process carried out by the Muara Enim regional government is still at a moderate level. For this reason, it is necessary to improve the quality of development planning so that businesses are attracted to integrate their CSR into local development program. Interviews were also carried out to deepen the results of the answers above. The results of in-depth interviews with 10 informants produced several interesting findings:

- Participatory Planning and Perception of Development Planning

Related to the perception of development planning, 7 informants agree and 2 informants are strongly agree that the development program is well planned. However, businesses perceived that a development program is well planned if community can be involved in the planning process of development program. Interview with informant related to their perception on well planned development program shows that:

"The planning process in the local Government starts from the Musrenbangdes (village development planning discussion) to the districts, so we confirm that the planning is truly aspirational from the community. The existence of musrenbangdes certainly helps. We no longer need to make our own deliberations ... "

\section{Informant 2}

Participatory planning carried out in the Musrenbangdes is a guarantee for businesses that the planning of development programs is an aspiration from the community. Musrenbangdes produce efficiency in the planning of CSR programs in business, so that they no longer need to hold a deliberation to capture the participation and aspirations of the community around their area, because this activity has been carried out by the local government.

\section{- Regional Government Integrity and Business Trust}

The democratic process through direct election of Bupati (Local district heads) creates legacy or authority over the planning carried out by the local government. However, this should be followed with a condition where local government should have integrity in the development program planning. These are an important factor in business perceptions and trust to the local 
governments. Business trust in Local Governments is based on this legacy, so businesses can submit the program planning process to Local Governments. This can be reflected from this interview which is stated:

"... if the Regional Government has the integrity to carry out the mandate given by the people, of course we believe in the regional government and the program. Another case, if the Regional Government has many problems, which causes the community to not trust the Regional Government, of course we think twice about integrating our CSR programs with regional development ..."

\section{Informant 5}

In this statement,integrity is a determining factor for businesses to be able to trust the local government and program planning that has been created by the local government.

- Adoption of business interests in Development Programs

The business perceptions of development programs and trust in local governments, resulted in 1 informant disagree about the local government can be trusted and the development program is well planned. The informants come from 1 company that responds to questions of perception different from the majority of other companies. In-depth interviews with the informant produced interesting findings, which caused the informant to give this perception.

"... in the Musrenbangdes, we are rarely involved so sometimes the programs netted in the deliberations are not in accordance with our program or the budget is insufficient ... But local governments sometimes force us to fund the program with our CSR budget"

\section{Informant 1}

As mentioned earlier, business interests in CSR should be considered when integrating CSR programs with regional development. Although regional development program planning results from participatory and aspirational processes, it is also necessary to pay attention to business interests in the proposed program. Business interests in CSR certainly cannot be separated from the profit goals of the business, so the interests of CSR to secure operations, obtain social licenses, and gain reputation must also be considered by local governments.

This process of integrating interests can be achieved by always involving business companies in musrenbangdes discussions held by local governments. In this forum, business companies can clarify directly some of the proposed community aspirations that have been submitted, adjusted to the objectives of the CSR program to be implemented by the company and also in accordance with the financing framework that has been prepared by the business company.

\subsection{Form of Integration Expected by Business}

After looking at business perceptions on development program planning and trust in Local Governments, the study also explores business expectations for forms of integration of CSR programs with regional development. In this case, 10 informants from business companies were asked questions about the integration model at the program planning stage and the program implementation stage. And also added the reasons for the chosen CSR program 
planning and implementation. In exploring this CSR program model, companies choose to implement it themselves or partner with local governments in the process of CSR planning and implementation.

Table 2. Expected Form of Integration

\begin{tabular}{|c|c|c|c|}
\hline Company & CSR Planning & CSR Implementation & Ratonale \\
\hline 1 & $\begin{array}{l}\text { Planning CSR Program } \\
\text { Directly to Community }\end{array}$ & $\begin{array}{l}\text { Implementing CSR } \\
\text { program directly to } \\
\text { community }\end{array}$ & $\begin{array}{l}\text { Focus on the Company's } \\
\text { Area, while the development } \\
\text { program is not focus on our } \\
\text { area }\end{array}$ \\
\hline 2 & $\begin{array}{l}\text { Partnership with Local } \\
\text { government in the } \\
\text { planning process }\end{array}$ & $\begin{array}{l}\text { Implementing CSR } \\
\text { program directly to } \\
\text { community }\end{array}$ & $\begin{array}{l}\text { Community may assume that } \\
\text { companies do not have CSR } \\
\text { if submitted to the local } \\
\text { government. }\end{array}$ \\
\hline 3 & $\begin{array}{l}\text { Aligning community } \\
\text { proposals to Local } \\
\text { Government programs. }\end{array}$ & $\begin{array}{l}\text { Implementation } \\
\text { support by } \\
\text { community }\end{array}$ & $\begin{array}{l}\text { To convince the community } \\
\text { with company efforts } \\
\text { through CSR }\end{array}$ \\
\hline 4 & $\begin{array}{l}\text { The company wants to } \\
\text { partner with the local } \\
\text { government to integrate } \\
\text { the program. }\end{array}$ & $\begin{array}{l}\text { The company } \\
\text { conducts CSR } \\
\text { program itself. }\end{array}$ & $\begin{array}{l}\text { Aimed to make CSR has } \\
\text { more effective impact to the } \\
\text { people directly affected. }\end{array}$ \\
\hline 5 & $\begin{array}{l}\text { Prefer to conduct CSR } \\
\text { planning directly with } \\
\text { community }\end{array}$ & $\begin{array}{l}\text { Carry out CSR } \\
\text { directly to the } \\
\text { community }\end{array}$ & $\begin{array}{l}\text { Community perception that } \\
\text { company is still lack of } \\
\text { giving CSR program }\end{array}$ \\
\hline 6 & $\begin{array}{l}\text { CSR Planning is } \\
\text { conducted by third } \\
\text { party }\end{array}$ & $\begin{array}{l}\text { Implementation is } \\
\text { carried out by the } \\
\text { company }\end{array}$ & $\begin{array}{l}\text { Community demand toward } \\
\text { CSR is high, while the CSR } \\
\text { budget is limited }\end{array}$ \\
\hline 7 & $\begin{array}{l}\text { Partnership with local } \\
\text { government } \\
\text { conducting discussion } \\
\text { with community } \\
\end{array}$ & $\begin{array}{l}\text { Implementation is } \\
\text { carried out by the } \\
\text { company }\end{array}$ & $\begin{array}{l}\text { Effectiveness of CSR budget } \\
\text { for affected group around the } \\
\text { company operation }\end{array}$ \\
\hline 8 & $\begin{array}{l}\text { Partnership with local } \\
\text { government } \\
\text { conducting discussion } \\
\text { with community } \\
\end{array}$ & $\begin{array}{l}\text { Implementation is } \\
\text { carried out by the } \\
\text { company }\end{array}$ & $\begin{array}{l}\text { Effectiveness of CSR budget } \\
\text { for affected group around the } \\
\text { company operation }\end{array}$ \\
\hline 9 & $\begin{array}{l}\text { Direct planning with } \\
\text { community }\end{array}$ & $\begin{array}{l}\text { Implementation is } \\
\text { carried out by the } \\
\text { company }\end{array}$ & $\begin{array}{l}\text { Company need the } \\
\text { community to know their } \\
\text { CSR program }\end{array}$ \\
\hline 10 & $\begin{array}{l}\text { Aligning community } \\
\text { proposal with local } \\
\text { government } \\
\text { development program }\end{array}$ & $\begin{array}{l}\text { Implementation is } \\
\text { carried out by the } \\
\text { company }\end{array}$ & $\begin{array}{l}\text { Company need the } \\
\text { community to know their } \\
\text { CSR program }\end{array}$ \\
\hline
\end{tabular}

Source: Interview, 2018 
The results of the interview tabulated above illustrate the response of informants to the integration of CSR programs and regional development models. In this section, the points of findings on the integration of CSR programs and regional development are as follows:

- Integration of CSR Planning and Regional Development Programs

Only 5 out of 10 informants stated that the integration of CSR program planning and regional development is needed. This is done by partnering directly with local governments in the preparation of CSR programs in business companies, or businesses that make their own internal adjustments to program inputs provided by local governments with proposals received from the public or their internal policies. It can be concluded, in the planning stage, program integration is still possible, even though business companies will not fully adopt the development programs proposed by the local government.

In this case, based on the results of interviews with business informants obtained the following explanation :

"... we can take programs created by the regional government, but we also receive proposals from the community. Later we can see, if the program proposed by the local government aligned with the proposal, surely that is what we prioritize. "

Informant 6

However, 5 other business informants stated that they did not want to integrate CSR programs with local government development programs. 5 informants stated that they prefer to do their own planning with the community through discussion and deliberation, or submit to the 3rd party who is competent in making CSR planning.

“... this is so that the public will know about our program. If everything is arranged by the local government, the community thinks it is a regional government program, not CSR. "

Informant 8

- Integration of the Implementation of CSR and Local Development Programs

In contrast to the planning stage, in the stages of implementing CSR programs, the 10 informants from business companies stated that they prefer to carry out CSR programs themselves, not together with the local government.

The reason for carrying out directly with the community is related to the implementation of CSR programs is inseparable from the interests of business companies to gain the reputation and trust of the local communities where they operate. In addition, direct implementation by business companies to local communities also guarantees the effectiveness of the program so that it is directly accepted by community groups directly affected by the company's operations.

\section{Conclusion}

Although the CSR obligations of business companies should be integrated with local development programs, in their implementation it is necessary to pay attention to several 
factors that underlie the decisions of business companies in carrying out CSR that cannot be released with the interests of the business companies themselves. Some of these important factors are:

1.Regional government integrity is a basic requirement that businesses want to integrate CSR programs with local government development programs. The integrity of the regional government is determined by the process of making development program plans that contain participatory and aspirational principles from the community.

2.Business interests in CSR programs that are inseparable from the business goals of generating profits cannot be eliminated, which is reflected in the business barriers to gain the trust and acceptance of the local community through CSR programs.

The ideal conditions in which regional development programs integrate with CSR programs must be accompanied by the following:

1. Involvement of business companies in village and district development meetings, so that businesses can directly adjust their CSR programs to the needs of the community and the vision and mission of the regional head. The process of negotiating and adjusting programs is still needed by businesses to incorporate local government development programs into their CSR programs.

2. Business interests in CSR must be considered in the process of integrating CSR programs and Local Government development programs. For this reason, local governments must pay attention and adopt these interests when integrating programs. Business interests such as security guarantees from the surrounding community, the company's reputation in the eyes of the community, to the social license of the community can be supported by the regional government as the holder of authority and legacy, by maintaining the integrity of the local government in harmonizing the basic problems in the region.

\section{References}

Ali, A. M., \& Yusof, H. (2011). Quality in qualitative studies: The case of validity, reliability and generalizability. Issues in Social and Environmental Accounting, 5(1/2), 25-64. https://doi.org/10.22164/isea.v5i1.59

Bappeda Muara Enim. (2019). Profil Forum CSR-PKBL Muara Enim.

Basri, H. (2014). Using qualitative research in accounting and management studies: not a new agenda. Journal of US-China Public Administration, 11(10), 831-838.

Carroll, A. B. (1991). The pyramid of corporate social responsibility: Toward the moral management of organizational stakeholders. Business horizons, 34(4), 39-48. https://doi.org/10.1016/0007-6813(91)90005-G 


\section{Macrothink}

Journal of Public Administration and Governance

ISSN 2161-7104

2020, Vol. 10, No. 2

Carroll, A. B., \& Shabana, K. M. (2010). The business case for corporate social responsibility: A review of concepts, research and practice. International journal of management reviews, 12(1), 85-105. https://doi.org/10.1111/j.1468-2370.2009.00275.x

Creswell, J. W., \& Poth, C. N. (2016). Qualitative inquiry and research design: Choosing among five approaches. Sage publications.

Donaldson, T., \& Dunfee, T. W. (1999). Ties that bind: A social contracts approach to business ethics.

Esa, R. F. (2016). Pertarungan Kepentingan Politik dalam Perumusan RPJM Daerah Kabupaten Mojokerto Tahun 2011-2015. Jurnal Politik Muda, 5(2), 256-267.

Famiyeh, S., Asante-Darko, D., Kwarteng, A., Gameti, D. K., \& Asah, S. A. (2019). Corporate social responsibility initiatives and its impact on social license: some empirical perspectives. Social Responsibility Journal. https://doi.org/10.1108/SRJ-06-2018-0147

Friedman, M. (2007). The social responsibility of business is to increase its profits. In Corporate ethics and corporate governance (pp. 173-178). Springer, Berlin, Heidelberg. https://doi.org/10.1007/978-3-540-70818-6_14

Graham, D., \& Woods, N. (2006). Making corporate self-regulation effective in developing $\begin{array}{llll}\text { countries. } \quad \text { World } & \text { 8velopment, }\end{array}$ https://doi.org/10.1016/j.worlddev.2005.04.022

Hasan, S. (2018). Sistem Perencanaan Pembangunan dalam Penataan Hukum Nasional. Meraja journal, 1(3).

Hinson, R. E., \& Ndhlovu, T. P. (2011). Conceptualising corporate social responsibility (CSR) and corporate social investment (CSI): the South African context. Social Responsibility Journal. https://doi.org/10.1108/17471111111154491

Marnelly, T. R. (2012). Corporate Social Responsibility (CSR) Tinjauan Teori dan Praktek di Indonesia. Jurnal Aplikasi Bisnis, 2(2), 49-59.

Nadjib, A. (2019). RKPD non-APBD. Jakarta: Indonesia Development Forum.

Nuryana, M., (2005). Corporate Social responsibility dan Kontribusi bagi Pembangunan Berkelanjutan, makalah yang disampaikan pada diklat pekerjaan sosial industri. Balai Besar Pendidikan dan Pelatihan Kesejahteraan Sosial (BBPPKS) Bandung, Lembang 5.

Partini, P. (2013). CSR Dan Pemberdayaan Masyarakat (Studi Implementasi Csr-ptba Di Muara Enim, Sumatera Selatan)(CSR and Community Development (Implementation Studies of CSR in Ptba in Muara Enim, South Sumatera Province). Jurnal Manusia dan Lingkungan 20, 94-99.

Patton, M. Q. (2014). Qualitative research \& evaluation methods: Integrating theory and practice. Sage publications. 


\section{Macrothink}

Journal of Public Administration and Governance ISSN 2161-7104 2020, Vol. 10, No. 2

Rachman, N. M., Efendi, A., \& Wicaksana, E. (2011). Panduan Lengkap Perencanaan CSR. Penebar Swadaya Grup.

Rahmayanti, D. R. (2014). Implementasi Corporate Social Responsibility dalam Membangun Reputasi Perusahaan.

Richardo, S., Nasution, B., \& WINDHA, W. (2013). Tanggung Jawab Direksi Dalam Menjalankan CSR (Corporate Social Responsibility) Berdasarkan Peraturan Pemerintah Nomor 47 Tahun 2012. Transparency Journal of Economic Law, 2(2), 14670.

Rosser, A., \& Edwin, D. (2010). The politics of corporate social responsibility in Indonesia. The Pacific Review, 23(1), 1-22. https://doi.org/10.1080/09512740903398314

Schwartz, M. S., \& Carroll, A. B. (2003). Corporate social responsibility: A three-domain approach. Business ethics quarterly, 13(4), 503-530. https://doi.org/10.5840/beq200313435

Zainal, R. I. (2006). Best practices: corporate social responsibility (CSR): sebuah pengalaman membangun multistakeholder engagement bagi penerapan CSR di Kabupaten Muba, Sumatera Selatan. Badan Penerbit Fakultas Ekonomi Unsri didukung oleh Partnership for Governance Reform in Indonesia, Uni Eropa, dan P3EM FE Unsri.

Zainal, R. I. (2019). Analysis of CSR Legislation in Indonesia: Mandate to Business. Business and Economic Research, 9(3), 165-181. https://doi.org/10.5296/ber.v9i3.14978

Zuhri, A. (2018). CSR Perusahaan 2018. di Kabupaten Muara Enim capai Rp, 88(71). Miliar. Sriwijaya Post.

\section{Copyright Disclaimer}

Copyright for this article is retained by the author(s), with first publication rights granted to the journal.

This is an open-access article distributed under the terms and conditions of the Creative Commons Attribution license (http://creativecommons.org/licenses/by/4.0/). 